\title{
Development of gluten-free cream puff with the addition of carboxymethylcellulose and carrageenan
}

\author{
${ }^{1 *}$ Penjumras P., ${ }^{1}$ Janmeesup, C., ${ }^{1}$ Umnat, S., ${ }^{1}$ Chokeprasert, P., ${ }^{1}$ Wattananapakasem, I. and \\ ${ }^{2}$ Phaiphan, A. \\ ${ }^{1}$ Program of Food Science and Technology, Maejo University-Phrae Campus, 54140 Rongkwang, Phrae, \\ Thailand. \\ ${ }^{2}$ Program of Food Science and Technology, Faculty of Agriculture Ubon Ratchathani Rajabhat University, \\ 34000 Ubon Ratchathani, Thailand.
}

\begin{abstract}
Article history:
October 2018

Available Online: 6

November 2018

Keywords:

Gluten-free,

Rice flour,

Bakery product,

Hydrocolloid
\end{abstract}

Received: 9 July 2018

Received in revised form: 21

Accepted: 24 October 2018

\section{DOI:}

https://doi/org/10.26656/fr.2017.3(2).133

\begin{abstract}
The consumption of gluten-free products is gaining attention since a growing number of people who suffer from celiac disease. However, many gluten-free products currently available in market are of low quality. The objective of this study was to evaluate the effect of the addition of carboxymethylcellulose and carrageenan on physical properties and sensory characteristics of cream puff made with $100 \%$ red brown jasmine rice flour. Cream puffs using $1 \%$ hydrocolloid at different concentrations of CMC mixed with carrageenan $(0.25 \%+0.75 \%, 0.50 \%+0.50 \%$, and $0.75 \%+0.25 \%)$ were developed and compared to a control sample prepared from wheat flour. The results showed that the use of rice flour reduced the effects of all physical properties and sensory characteristics. Compared to control, cream puff made with rice flour had a lower specific volume and darker. However, the incorporation of $0.50 \% \mathrm{CMC}$ mixed with $0.50 \%$ carrageenan presented quality attributes similar to that of the control sample due to hydrocolloids act as polymeric substances that should mimic the viscoelastic of gluten. Therefore, it is feasible for gluten-free cream puff application.
\end{abstract}

\section{Introduction}

Among cereals, wheat has specific proteins that make it ideal for certain applications. The unique properties of wheat are generally ascribed to the viscoelastic properties of its gluten proteins. While monomeric gluten proteins (gliadin) show viscous behavior, polymeric gluten proteins (glutenin) are elastic (Veraverbeke and Delcour, 2002). Thus, wheat gliadins and glutenins, in the presence of water and mechanical work, form a continuous phase named gluten network. It is responsible for the extensible and cohesive properties of the dough while reducing its stickiness. Wheat dough is characterized for its tenacity, dough resistance to stretching and elasticity, dough ability to regain its original shape after being stretched. The unique elasticity of glutenin results to a large extent from its polymeric nature. Glutenin is a highly heterogeneous mixture of polymers consisting of a number of different high- and low-molecular-weight glutenin subunits linked by disulfide bonds (Veraverbeke and Delcour, 2002; Gómez and Sciarini, 2015). A variety of cereal foods are produced from wheat flour, such as bread, cake and pasta, all of which, contain gluten. However, many people suffer from gluten-related disorders. Celiac disease, also known as gluten intolerance to certain amino acid sequences found in the prolamin fraction of wheat (gliadin), rye (secalin) and barley (hordein) (Itthivadhanapong et al., 2016). Gluten replacement is one of the most challenging issues for food science and technology since finding high-quality gluten-free foods is a major issue for celiac disease sufferers (Turabi et al., 2010; Itthivadhanapong et al., 2016). Among gluten-free raw materials that can be used for this purpose, the most important ones are cereal flours without gluten, as well as native starches. Rice flour is one of the most suitable raw materials due to its hypoallergenic properties, low sodium content, bland taste, and its easy availability in the market (Torbica et al., 2012). Nowadays, the consumption of pigmented rice such as brown, red, purple or black pericarp has gain attention in some Asian countries (Jeng et al., 2012). Pigmented rice is also known as a source of antioxidant compounds including flavonoid, anthocyanin, phytic acid, proanthocyanidin, tocopherols, tocotrienols, $\gamma$-oryzanol, and phenolic 
compounds (Butsat and Siriamornpun, 2010; Goufo and Trindade, 2014; Thitipramote et al., 2016). Thitipramote et al. (2016) reported that two native Thai pigmented rice (Brown red jasmine rice and Kam leumpua; black rice) compose of the higher phenolic compounds and greater antioxidant activities than Japanese brown rice. The greatest amount of these compounds and activities was found in red rice (Brown red jasmine rice). The phytochemical in pigmented rice, such as phenolics and anthocyanins are related with reducing the risk of developing chronic diseases, such as diabetes, obesity, cancer, and cardiovascular disease (Mau et al., 2017). Some bakery products have been studied on the use of rice flour as a replacement for wheat flour, such as rice flour cake containing lupin flour and whole buckwheat flour (Levent and Bilgiçli, 2011); chiffon cake prepared with black rice (Mau et al, 2017); yellow cake prepared from rice flour and peanut paste (Jaganathan, 2016), and white bread made from rice flour mixed with cornstarch and cassava starch (López et al., 2004). However, the use of rice flour to prepare cream puff has not been exploring yet. Thus, it would be beneficial to develop a novel formula for cream puff made from red jasmine rice. The replacement of gluten presents a major technological challenge, as it is an essential structurebuilding protein. To tackle this problem, hydrocolloids were incorporated in gluten-free flour to mimic the viscoelastic properties of gluten (Lazaridou et al., 2007; Pahwa et al., 2016). The addition of hydrocolloids in gluten-free formulation products is necessary in order for the hydrocolloids to act as polymeric substances that should mimic the viscoelastic properties of gluten and increase the dough's gas-retaining ability (Sabanis and Tzia, 2011). The hydrocolloid reduced the availability of water for granule swelling. The increased viscosity thereby increased the shear forces exerted on the swollen granules, thus increasing the breakdown viscosity. Associations between starch polymer molecules and hydrocolloid molecules could be responsible for the increase in the setback and final viscosity. Hydrocolloid molecules bound water reduced the mobility of the starch chains and thereby retard retrogradation (Satrapai and Suphantharika, 2007). Therefore, the purpose of this study was to develop gluten-free cream puff with the addition of hydrocolloids including carboxymethylcellulose and carrageenan.

\section{Materials and methods}

\subsection{Materials}

Commercial red brown jasmine rice was purchased from the local market in Phrae province, Thailand (Kaijae brand, Thailand). All-purpose wheat flour (Kite brand, UFM Food Center Co., Ltd, Thailand), cake flour (Red Lotus brand, UFM Food Center Co., Ltd,
Thailand), butter (Allowri brand), margarine (Best Foods, Thailand) and fresh whole eggs ( 50 g/piece) were used in this study, carboxymethylcellulose (CMC) and carrageenan were purchased from Union Science Co., Ltd. Thailand.

Red jasmine rice was ground using blender (Model HR 2115, Philips, Indonesia), and screened through a 150-mesh sieve five times. The rice powder was contained in an airtight box and then kept at room temperature $\left(\sim 25^{\circ} \mathrm{C}\right)$ before use.

\subsection{Analysis of chemical composition of wheat flour and rice flour}

Moisture content (oven at $105^{\circ} \mathrm{C}$ ), Ash content (muffle furnace at $550-600^{\circ} \mathrm{C}$ ), lipids (Soxhlet method), proteins (Kjeldahl method) and fiber were evaluated according to the official methods of the AOAC (2012). Total carbohydrates were calculated following equation (1).

Total Carbohydrates $=100-$ [weight in grams (moisture + ash + lipid + protein)] in $100 \mathrm{~g}$ of food

\subsection{Preparation of cream puff}

The basic cream puff recipe was chosen according to our preliminary study. The control cream puff formulation contained the following ingredients: $120 \mathrm{~g}$ all-purpose wheat flour, 120 cake flour, $480 \mathrm{~g}$ water, 75 $\mathrm{g}$ butter, $75 \mathrm{~g}$ margarine and $350 \mathrm{~g}$ fresh whole egg. For red jasmine rice flour cream puff, $100 \%$ rice flour $(240 \mathrm{~g}$ rice flour) was used to substitute wheat flour. CMC and carrageenan were added in $1 \%$ of flour basis. Cream puffs using $1 \%$ hydrocolloid at different concentrations of CMC mixed with carrageenan $(0.25 \%+0.75 \%, 0.50 \%$ $+0.50 \%$, and $0.75 \%+0.25 \%$ ). The cream puffs made from rice flour without hydrocolloid were also prepared. The cream puffs were manufactured using the following steps: flour was sieved through a 150 -mesh sifter. Butter and margarine were then mixed in boiled water and stirred vigorously over low heat until mixture left the pan. The mixture was removed from heat and let it cool for 5 mins. Hydrocolloid was dissolved in cold water and blended with the mixture. Eggs were beaten with the mixture until smooth and velvety. The mixture was dropped onto a baking tray and baked in preheated oven $200^{\circ} \mathrm{C}$ for 20 mins. Cream puff was removed from the oven, cooled for $1 \mathrm{hr}$ and kept in an airtight box and put in freezer at $8^{\circ} \mathrm{C}$ until analysis.

\subsection{Physical characteristics of batters}

The viscosity of batter was performed with a viscometer (RVT, Brookfield viscometer, USA). The $400 \mathrm{~mL}$ of cream puff batter was poured into a $500 \mathrm{~mL}$ beaker and its viscosity was measured. The specific 
gravity of batter was determined by dividing the weight of a standard container filled with batter by the same container filled with water ( $\mathrm{Lu}$ et al., 2010). Each analysis was carried out in triplicates.

\subsection{Physical characteristics of cream puffs}

The physical characteristics of cream puff, including specific volume, color, weight loss and moisture content. The specific volume $\left(\mathrm{mL} \cdot \mathrm{g}^{-1}\right)$ of the cream puff batter was obtained by the ratio between the apparent volume $(\mathrm{mL})$ and the cream puff mass $(\mathrm{g})$ after baking. The mass was obtained by weighing the cream puff on a precision scale (Ohaus, Pioneer PA214, USA). The apparent volume of the cream puff was determined by the method of displacement of sesame seeds (Mau et al., 2017). The color of the cream puffs was measured using a colorimeter (Color Flex 500, Hunter Lab, USA). Results were expressed in CIE $L^{*} a^{*}$ and $b^{*}$ values. The cream puffs were weighted before baking $\left(\mathrm{W}_{0}\right)$ and after baking and 1-hour cooling $\left(\mathrm{W}_{1}\right)$. The weight loss was calculated using equation (2) (Matos et al., 2014). Moisture content was measured according to the official methods of the AOAC (2012).

$$
\text { Weight loss }(\%)=\frac{\left(\mathrm{W}_{0}-\mathrm{W}_{1}\right) \times 100}{\mathrm{~W}_{\mathrm{n}}}
$$

\subsection{Sensory evaluation}

The degree of overall preference for baked cream puffs was determined by hedonic scale test (Mau et al., 2017). The untrained panelists were recruited from the students and staff at Maejo University-Phrae Campus. All untrained panelists were informed on how to evaluate cream puff. The 50 panelists received 5 samples and were asked to rate them based on the degree of preference on a 7-point hedonic scale $(1=$ dislike extremely, $4=$ neither like nor dislike, and $7=$ like extremely). Panelists evaluated the samples in a testing area and were instructed to rinse their mouths with water between samples to minimize any residual effect.

\subsection{Statistical analysis}

Data were subjected to Analysis of Variance (ANOVA) using SPSS for Window version 24. In case of any differences in mean, multiple comparisons were performed using Duncan's Multiple Range Test (DMRT) at $5 \%$ level of significance $(\mathrm{P} \leq 0.05)$.

\section{Results and discussion}

\subsection{Chemical composition of raw materials}

The results for the chemical composition of the wheat flours and red jasmine rice flour are presented in Table 1. The composition of all-purpose flour on a wet basis was $11.73 \%$ moisture, $0.49 \%$ ash, $0.77 \%$ fat, $7.68 \%$ protein, and $79.34 \%$ carbohydrates. The similar composition was found in cake flour, but lower in protein content with $7.08 \%$ then resulting higher of carbohydrates. Meanwhile, the composition of rice flour was $10.49 \%$ moisture, $0.49 \%$ ash, $1.88 \%$ fat, $6.16 \%$ protein, and $80.98 \%$ carbohydrates.

The results indicated that rice flour had lower in protein content compared to wheat flour (all-purpose and cake flour) but higher in lipid and fiber. The results showed different composition with previous work carried out by Vallejos et al. (2015). They reported the chemical composition of the rice flour on a dry basis was $7.52 \%$ protein, $0.41 \%$ fat, $0.31 \%$ ash, and $91.76 \%$ carbohydrates. This may be related to this recent study reported on a wet basis.

\subsection{Physical characteristics of batters}

The foremost reason behind the ample use of hydrocolloids in food is their ability to modify the rheology of the food system, namely flow behavior (viscosity) (Saha and Bhattacharya, 2010). The effect of the addition of hydrocolloids on physical characteristics of the batters after complete substitution of the wheat flour by red jasmine rice flour is presented in Table 2 .

Table 2. Physical characteristics of cream puff batter

\begin{tabular}{ccc}
\hline Batter samples & Viscosity $(\mathrm{cP})^{\mathrm{ns}}$ & Specific gravity \\
\hline Wheat flour & $20,000 \pm 0$ & $1.10 \pm 0.05^{\mathrm{a}}$ \\
\hline Rice flour $(\mathrm{CMC}$ : carrageenan) & \\
\hline $0: 0$ & $18,533 \pm 461$ & $0.89 \pm 0.02^{\mathrm{c}}$ \\
$0.25: 0.75$ & $19,266 \pm 702$ & $1.07 \pm 0.01^{\mathrm{a}}$ \\
$0.50: 0.50$ & $19,667 \pm 577$ & $1.08 \pm 0.01^{\mathrm{a}}$ \\
$0.75: 0.25$ & $20,000 \pm 0$ & $1.04 \pm 0.00^{\mathrm{b}}$ \\
\hline
\end{tabular}

*Values followed by the different letter within the same column are significantly different from each other $(\mathrm{p} \leq 0.05)$. ** Values followed by ns within the same column are not significantly different from each other $(\mathrm{p}>0.05)$.

Table 1. Chemical composition of wheat flour and rice flour

\begin{tabular}{lcccccc}
\hline \multirow{2}{*}{ Samples } & \multicolumn{5}{c}{ Chemical compositions (\%) } \\
\cline { 2 - 7 } & Moisture $^{\mathrm{ns}}$ & Ash $^{\mathrm{ns}}$ & Lipid & Protein & Fiber & Carbohydrates \\
\hline All-purpose flour & $11.73 \pm 0.52$ & $0.49 \pm 0.01$ & $0.77 \pm 0.01^{\mathrm{b}}$ & $7.68 \pm 0.01^{\mathrm{a}}$ & $0.71 \pm 0.15^{\mathrm{b}}$ & $79.34 \pm 0.01^{\mathrm{b}}$ \\
Cake flour & $11.74 \pm 0.80$ & $0.49 \pm 0.00$ & $0.77 \pm 0.00^{\mathrm{b}}$ & $7.08 \pm 0.00^{\mathrm{a}}$ & $0.56 \pm 0.11^{\mathrm{b}}$ & $79.92 \pm 0.00^{\mathrm{b}}$ \\
Rice flour & $10.49 \pm 0.48$ & $0.49 \pm 0.01$ & $1.88 \pm 0.42^{\mathrm{a}}$ & $6.16 \pm 0.42^{\mathrm{b}}$ & $2.08 \pm 0.21^{\mathrm{a}}$ & $80.98 \pm 0.42^{\mathrm{a}}$ \\
\hline
\end{tabular}

*Values followed by the different letter within the same column are significantly different from each other $(\mathrm{p} \leq 0.05)$.

** Values followed by ns within the same column are not significantly different from each other $(\mathrm{p}>0.05)$. 
The specific gravity of batters estimates the air incorporated into a batter, a lower specific gravity indicates of a batter with more air and viscosity. All batter had a specific gravity higher than 0.75 indicating a stable emulsion (Lin et al., 1994; Singh, 2012). The viscosity of all cream puff batter did not differ significantly with replacing rice flour instead of wheat flour. The similar result was found by Mau et al. (2017) who used black rice flour as a replacement for wheat flour in chiffon cake. However, the viscosity of batter prepared from rice flour increased slightly with the addition of hydrocolloids, especially the increase of CMC ratio. Sidhu and Bawa (2000) reported that CMC involve its interaction with water. Carboxymethylcellulose interacts with protein molecules to provide suspension and solution stability. They found that the increase of CMC affected the increase of water absorption in bread batter. A decrease in the specific volume of batters was observed with the substitution of the wheat flour by red jasmine rice flour. This could be related the higher in lipid content as shown in Table 1 then resulting in lower specific gravity.

\subsection{Physical characteristics of cream puffs}

The effect of the addition of hydrocolloids on physical characteristics of cream puffs was investigated. The results are presented in Table 3.

From Table 3, the specific volume, weight loss, moisture and color of rice flour cream puff differed significantly compared to wheat flour cream puff. The cream puff prepared from wheat flour showed higher specific volume. This is related to higher weight loss then resulting in lower moisture content and resulting thin crust as shown in Figure 1. Cream puff structure setting must be timed so that the air bubble can properly be expanded by water vapor before it sets. Thus, the resulting puff structure is highly aerated and has a more defined structure. In this study, there was no difference among viscosity of all formula puff batter. However, the gluten of batter decreased when wheat flour was replaced with rice flour, and thus, the ability to retain air was poorer which produced the undesirable aerated structure with lower volume (Mau et al., 2017). Basically, the addition of hydrocolloids in gluten-free formulation products is necessary in order to act as polymeric substances that can mimic the viscoelastic properties of gluten and increase the dough's gas-retaining ability (Sabanis and Tzia, 2011). However, this recent study demonstrated that the addition of hydrocolloids did not increase the dough's gas-retaining ability but increase water absorption. It can be seen from higher moisture content in the final product. From Table 3, the result summarized that rice flour puff without the addition of hydrocolloid provided better physical characteristics than the addition of hydrocolloids. However, this study found that the rice puff's structure without the addition of hydrocolloid had weak crust structure during storage.

The Hunter, $\mathrm{L}^{*}, \mathrm{a}^{*}$ and $\mathrm{b}^{*}$, values correspond to lightness, redness, and yellowness, respectively. The crust color of baked puff was greatly affected by replacing wheat flour with rice flour as shown in Table 3 . The $L^{*}$ and $b^{*}$ values decrease but $a^{*}$ value increased, indicating that a darker, redder, and less yellow was obtained as a result of red jasmine rice replacement. The colors of pigmented rice as red jasmine rice attributes to anthocyanins and proanthocyanin which present the red or purple color (Min et al., 2011).

\subsection{Sensory characteristics}

Sensory characteristics were tested to evaluate acceptance by the consumer as shown in Table 4 .

From Table 4, wheat flour cream puff demonstrated appearance, color, flavor, taste, texture and overall acceptance scores of 5.76, 6.10, 5.40, 4.68, 5.42 and 5.04, respectively. Meanwhile, rice flour cream puff showed appearance, color, flavor, taste, texture and overall acceptance scores in the range of 4.98-5.04, 5.24$5.46,4.64-4.92,4.00-4.36,4.58-5.02$ and 4.34-4.54, respectively. Although the substitution of wheat flour with red jasmine rice flour led to significantly decreased sensory characteristics the decrease of the score for all characteristics was less than 1 scale. In addition, all sensory characteristics of rice cream puff had scored higher than 4 . This means that panelists accepted cream puff made from rice flour. When compared between baked rice flour cream puff, there was no difference among the appearance, color, flavor and overall acceptance score for all cream puff. However, the taste score of rice flour cream puff adding CMC: carrageenan with 0.50:0.50 did not differ significantly compared to wheat flour cream puff. Moreover, rice flour cream puff adding CMC: carrageenan with 0.50:0.50 had the highest score of color, flavor, taste and texture compared to other rice flour cream puff. In addition, it provided the highest specific volume as shown in Table 3. Therefore, the optimum red jasmine rice flour cream puff was the addition of CMC: carrageenan with 0.50:0.50.

\section{Conclusion}

The addition of hydrocolloids significantly affected some characteristics of rice flour cream puff. The ratio CMC: carrageenan with 0.50:0.50 increased cream puff's specific volume and had highest sensory score. The sensory qualities of each characteristic were 4.38-5.46 on a 7-point hedonic scale, indicated that the cream puff was moderately acceptable. Therefore, red jasmine rice 
Table 3. Physical characteristics of baked cream puffs

\begin{tabular}{|c|c|c|c|c|c|c|}
\hline \multirow{2}{*}{$\begin{array}{l}\text { Cream puff } \\
\text { samples }\end{array}$} & \multirow{2}{*}{$\begin{array}{l}\text { Specific volume } \\
\qquad\left(\mathrm{mL} \cdot \mathrm{g}^{-1}\right)\end{array}$} & \multirow{2}{*}{$\begin{array}{l}\text { Weight loss } \\
(\%)\end{array}$} & \multirow{2}{*}{$\begin{array}{l}\text { Moisture } \\
(\%)\end{array}$} & \multicolumn{3}{|c|}{ Color } \\
\hline & & & & $\mathrm{L}^{*}$ & $\mathrm{a}^{*}$ & $b^{*}$ \\
\hline Wheat flour & $5.11 \pm 0.19^{\mathrm{a}}$ & $26.16 \pm 1.78^{\mathrm{a}}$ & $8.08 \pm 0.30^{\mathrm{a}}$ & $58.82 \pm 0.29^{\mathrm{a}}$ & $4.56 \pm 0.11^{\mathrm{e}}$ & $39.60 \pm 0.12^{a}$ \\
\hline \multicolumn{7}{|c|}{ Rice flour (CMC: carrageenan) } \\
\hline $0: 0$ & $4.41 \pm 0.28^{\mathrm{b}}$ & $22.45 \pm 2.32^{\mathrm{b}}$ & $8.25 \pm 0.51^{\mathrm{b}}$ & $38.91 \pm 0.32^{\mathrm{d}}$ & $8.04 \pm 0.42^{\mathrm{c}}$ & $30.27 \pm 0.39^{\mathrm{d}}$ \\
\hline $0.25: 0.75$ & $2.55 \pm 0.14^{\mathrm{d}}$ & $21.19 \pm 2.82^{\mathrm{c}}$ & $8.95 \pm 0.22^{\mathrm{b}}$ & $46.48 \pm 0.20^{\mathrm{b}}$ & $7.64 \pm 0.11^{\mathrm{d}}$ & $29.37 \pm 0.19^{\mathrm{e}}$ \\
\hline $0.50: 0.50$ & $3.33 \pm 0.24^{\mathrm{c}}$ & $21.32 \pm 2.49^{\mathrm{c}}$ & $8.92 \pm 0.09^{\mathrm{b}}$ & $45.73 \pm 0.03^{\mathrm{c}}$ & $9.49 \pm 0.12^{\mathrm{b}}$ & $35.52 \pm 0.49^{b}$ \\
\hline $0.75: 0.25$ & $3.31 \pm 0.27^{\mathrm{c}}$ & $21.15 \pm 2.39^{c}$ & $8.75 \pm 0.31^{b}$ & $38.91 \pm 0.32^{\mathrm{d}}$ & $10.04 \pm 0.33^{\mathrm{a}}$ & $34.09 \pm 0.71^{\mathrm{c}}$ \\
\hline
\end{tabular}

*Values followed by the different letter within the same column are significantly different from each other $(\mathrm{p} \leq 0.05)$.

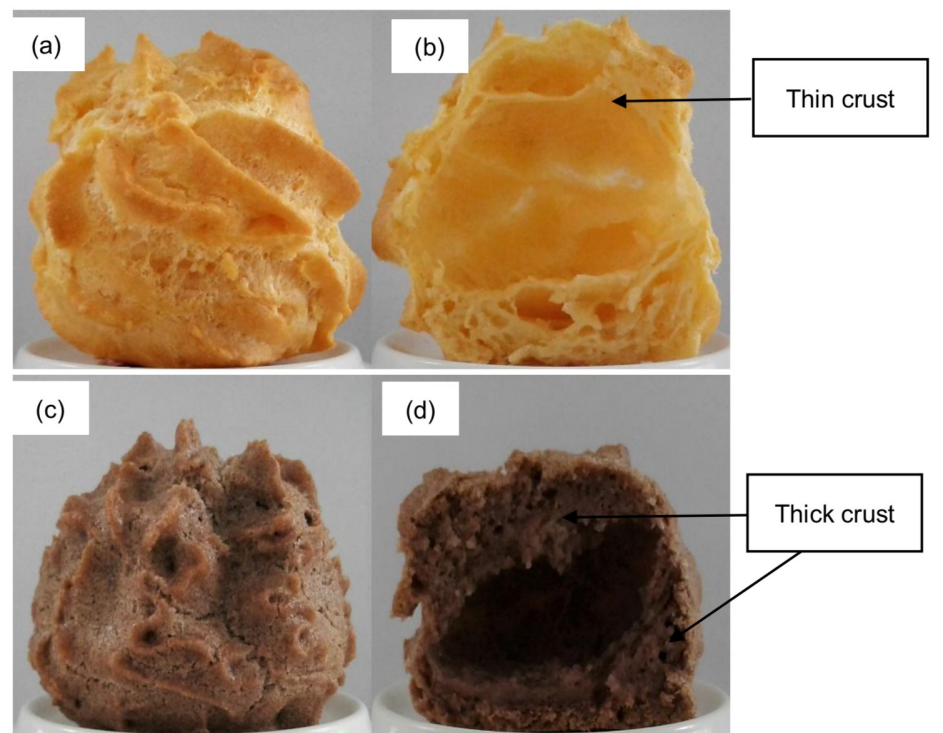

Figure 1. Photograph of cream puffs (a) wheat flour cream puff; (b) wheat flour cream puff crust; (c) rice flour cream puff without hydrocolloid; (d) rice flour cream puff crust without hydrocolloid

Table 4. Sensory characteristics of baked cream puff

\begin{tabular}{ccccccc}
\hline Cream puff samples & Appearance & Color & Flavor & Taste & Texture & Overall Acceptance \\
\hline Wheat flour & $5.76 \pm 1.06^{\mathrm{a}}$ & $6.10 \pm 0.91^{\mathrm{a}}$ & $5.40 \pm 1.40^{\mathrm{a}}$ & $4.68 \pm 1.74^{\mathrm{a}}$ & $5.42 \pm 1.34^{\mathrm{a}}$ & $5.04 \pm 1.48^{\mathrm{a}}$ \\
\hline Rice flour (CMC: carrageenan) & & & & & & \\
\hline $0: 0$ & $5.04 \pm 1.24^{\mathrm{b}}$ & $5.44 \pm 1.05^{\mathrm{b}}$ & $4.64 \pm 1.31^{\mathrm{b}}$ & $4.18 \pm 1.65^{\mathrm{b}}$ & $4.78 \pm 1.52^{\mathrm{bc}}$ & $4.34 \pm 1.65^{\mathrm{b}}$ \\
$0.25: 0.75$ & $4.98 \pm 1.27^{\mathrm{b}}$ & $5.38 \pm 1.03^{\mathrm{b}}$ & $4.84 \pm 1.53^{\mathrm{b}}$ & $4.28 \pm 1.77^{\mathrm{b}}$ & $4.80 \pm 1.54^{\mathrm{bc}}$ & $4.54 \pm 1.56^{\mathrm{b}}$ \\
$0.50: 0.50$ & $5.00 \pm 1.34^{\mathrm{b}}$ & $5.46 \pm 1.13^{\mathrm{b}}$ & $4.92 \pm 1.43^{\mathrm{b}}$ & $4.36 \pm 1.72^{\mathrm{ab}}$ & $5.02 \pm 1.44^{\mathrm{b}}$ & $4.38 \pm 1.52^{\mathrm{b}}$ \\
$0.75: 0.25$ & $5.04 \pm 1.24^{\mathrm{b}}$ & $5.24 \pm 1.09^{\mathrm{b}}$ & $4.76 \pm 1.36^{\mathrm{b}}$ & $4.00 \pm 1.55^{\mathrm{b}}$ & $4.58 \pm 1.54^{\mathrm{c}}$ & $4.52 \pm 1.40^{\mathrm{b}}$ \\
\hline
\end{tabular}

*Values followed by the different letter within the same column are significantly different from each other $(\mathrm{p} \leq 0.05)$.

flour cream puff could be developed as an alternative bakery product for consumers who suffer from celiac disease and a novel functional food with antioxidant properties due to rich in bioactive compound.

\section{Acknowledgment}

The authors would like to acknowledge Maejo University-Phrae Campus for laboratory equipment support.

\section{References}

AOAC. (2012). Official method of analysis of AOAC International. $19^{\text {th }}$ ed. Virginia: Association of Official and Analytical Chemists International.

Butsat, S. and Siriamornpun, S. (2010). Antioxidant capacities and phenolic compounds of the husk, bran and endosperm of Thai rice. Food Chemistry, 119, 606-613. https://doi.org/10.1016/ j.foodchem.2009.07.001

Gómez, M. and Sciarini, L.S. (2015). Gluten-free bakery products and pasta. In Arranz, E., FernándezBañares, F., Rosell C.M., Rodrigo, L. and Peña, A.S. (Eds). Advances in the understanding of gluten related pathology and the evolution of gluten-free foods, p. 565-604. Barcelona, Spain: Omnia Science. https://doi.org/10.3926/oms.265

Goufo, P. and Trindade, H. (2014). Rice antioxidants: phenolic acids, flavonoids, anthocyanins, proanthocyanidins, tocopherols, tocotrienols, $\gamma$ oryzanol, and phytic acid. Food Science and Nutrition, 2(2), 75-104. https://doi.org/10.1002/ fsn3.86 
Itthivadhanapong, P., Jantathai, S. and Schleining, G. (2016). Improvement of physical properties of gluten -free steamed cake based on black waxy rice flour using different hydrocolloids. Journal of Food Science and Technology, 53(6), 2733-2741. https:// doi.org/10.1007/s13197-016-2245-5

Jaganathan, A. (2016). Production of rice flour and peanut paste in yellow cake. International Journal of Science and Research, 5(8), 1410-1413.

Jeng, T.L., Lai, C.C., Ho, P.T., Shih, Y.J. and Sung, J.M. (2012). Agronomic, molecular and antioxidative characterization of red-and purple-pericarp rice (Oryza sativa L.) mutants in Taiwan. Journal of Cereal Science, 56, 425-431. https://doi.org/10.1016/ j.jcs.2012.05.015

Lazaridou, A., Duta, D., Papageorgiou, M., Belc, N. and Biliaderis, C.G. (2007). Effects of hydrocolloids on dough rheology and bread quality parameters in gluten-free formulations. Journal of Food Engineering, 79(3), 1033-1047. https:// doi.org/10.1016/j.jfoodeng.2006.03.032

Levent, H. and Bilgiçli, N. (2011). Effect of gluten-free fours on physical properties of cakes. Journal of Food Science and Engineering, 1, 354-360. https:// doi.org/10.1590/S1516-89132004000100009

Lin, P.Y., Czuchajowska, Z. and Pomeranz, Y. (1994). Enzyme-resistant starch in yellow layer cake. Cereal Chemistry, 71, 69-75.

López, A.C.B., Pereira, A.J.G. and Junqueira, R.G. (2004). Flour mixture of rice flour, corn and cassava starch in the production of gluten-free white bread. Brazilian Archives of Biology and Technology, 47 (1), 63-70.

Lu, T.M., Lee, C.C., Mau, J.L. and Lin, S.D. (2010). Quality and antioxidants of green tea powder. Journal of Food Processing and Preservation, 39, 443-450.

Matos, M.E., Sanz, T. and Rosell, C.M. (2014). Establishing the function of proteins on the rheological and quality properties of rice based gluten free muffins. Food Hydrocolloids, 35, 150158. https://doi.org/10.1016/j.foodhyd.2013.05.007

Mau, J.L., Lee, C.C., Chen, Y.P. and Lin, S.D. (2017). Physicochemical, antioxidant and sensory characteristics of chiffon cake prepared with black rice as replacement for wheat flour. Food Science and Technology, 75, 434-439.

Min, B., McClung, A.M. and Chen, M.H. (2011). Phytochemicals and antioxidant capacities in rice brans of different color. Journal of Food Science, 76, 117-126. https://doi.org/10.1111/j.1750-

3841.2010.01929.x
Pahwa, A., Kaur, A. and Puri, R. (2016). Influence of hydrocolloids on the quality of major flat breads: A review. Journal of Food Processing, 2016, 1-9. https://doi.org/10.1155/2016/8750258

Sabanis, D. and Tzia, C. (2011). Effect of hydrocolloids on selected properties of gluten-free dough and bread. Food Science and Technology International, 17(4), 279-291. https:// doi.org/10.1177/1082013210382350

Saha, D. and Bhattacharya, S. (2010). Hydrocolloids as thickening and gelling agent in food: A Critical Review. Journal of Food Science and Technology, 47(6), 587-597. https://doi.org/10.1007/s13197-010$0162-6$

Satrapai, S. and Suphantharika, M. (2007). Influence of spent brewer's yeast $\beta$-glucan on gelatinization and retrogradation of rice starch. Carbohydrate Polymers, 67(4), 500-510. https://doi.org/10.1016/ j.carbpol.2006.06.028

Sidhu, J.P.S. and Bawa, A.S. (2000). Incorporation of carboxymethylcellulose in wheat flour: Rheological, alveographic, dough development, gas formation/ retention, baking and bread firmness studies. International Journal of Food Properties, 3(3), $407-$ 419. https://doi.org/10.1080/10942910009524645

Singh, M. (2012). Effect of flour-oil composite as powdered fat source in low-fat cake mixes. Journal of Food Processing and Technology, 3(154), 1-5. https://doi.org/10.4172/2157-7110.1000154

Thitipramote, N., Pradmeeteekul, P., Nimkamnerd, J., Chaiwut, P., Pintathong, P. and Thitilerdecha, N. (2016). Bioactive compounds and antioxidant activities of red (Brown Red Jasmine) and black (Kam Leum Pua) native pigmented rice. International Food Research Journal, 23(1), 410414.

Torbica A., Hadnađev, M. and Dapčević Hadnađev, T. (2012). Rice and buckwheat flour characterisation and its relation to cookie quality. Food Research International, 48, 277-283. https://doi.org/10.1016/ j.foodres.2012.05.001

Turabi, E., Sumnu, G. and Sahin, S. (2010). Quantitative analysis of macro and micro-structure of gluten-free rice cakes containing different types of gums baked in different ovens. Food Hydrocolloids, 24, 755762. https://doi.org/10.1016/j.foodhyd.2010.04.001

Vallejos, V.B., Crizel, T.M. and Salas-Mellado, M.M. (2015). Development of gluten-free cakes with the addition of methylcellulose and xanthan gum. Semina: Ciências Agrárias, Londrina, 36(3), 13171328. https://doi.org/10.5433/16790359.2015v36n3p11317 
Veraverbeke, W.S. and Delcour, J.A. (2002). Wheat protein composition and properties of wheat glutenin in relation to breadmaking functionality: A Critical Reviews, Food Science and Nutrition, 42(3), 179208. https://doi.org/10.1080/10408690290825510 